\title{
Seasonal variation of male-type antennular setation in female Calanus finmarchicus
}

\author{
Charles B. Miller ${ }^{1, *}$, Jennifer A. Crain ${ }^{1}$, Nancy H. Marcus ${ }^{2}$ \\ ${ }^{1}$ College of Oceanic and Atmospheric Sciences, Oregon State University, Corvallis, Oregon 97331-5503, USA \\ ${ }^{2}$ Department of Oceanography, Florida State University, Tallahassee, Florida 32306, USA
}

\begin{abstract}
Female calanoid copepods of the family Calanidae can mature with either the juvenile and most typical female pattern of setation, termed trithek $(\mathrm{T})$, or with the male pattern, termed quadrithek (Q). It was suggested by Fleminger (1985), but not proved, that females with the Q pattern have switched from development as males to development as females after initiation of seta formation prior to the maturation molt. Such switching, if it occurs, has population dynamical consequences. Therefore, we determined the fractions of $\mathrm{Q}$ females in the population of Calanus finmarchicus from Georges Bank and nearby deeper water during each month of the animals' growing season, January through July of 1995. Based on $>780$ individuals examined from each month, the fraction of Q individuals was 20\% in January, decreased to $8.5 \%$ in April, rose to $12.5 \%$ in June and was $9 \%$ in July. This suggests that the individuals of the several seasonal generations select reproduction as females (or conversely as males) at different rates. Smaller samples from January, April and June of 1996 showed the same pattern. A similar study in a northern Norwegian fjord with 1 annual generation (Svensen \& Tande 1999) showed 38\% Q females in February, early in maturation, and $25 \% \mathrm{Q}$ in March. If proportions of individuals selecting male or female reproduction are somehow optimized in response to habitat circumstances, then variation in fraction of $Q$ females implies that the optimum is different in different seasons and latitudes. It remains to explain the implied differences in the reproductive value (in the sense established by Fisher 1930) of female versus male reproduction in Calanus.
\end{abstract}

KEY WORDS: Calanus finmarchicus $\cdot$ Copepod $\cdot$ Antennules $\cdot$ Sex determination $\cdot$ Georges Bank Resale or republication not permitted without written consent of the publisher

\section{INTRODUCTION}

Adult males in many groups of calanoid copepods normally have more aesthetascs, sac-like chemosensory setae, on their antennules than do females. In the family Calanidae (Calanus, Neocalanus and related genera) copepodites and most females have 3 setae on each primitive antennular segment, 2 simple setae and 1 aesthetasc. Fleminger (1985) termed that the trithek pattern ( $\mathrm{T}$, from here on). Males have an additional aesthetasc on each of Segments $2 b$ (Segment 2 is a fusion of 3 primitive segments, $2 \mathrm{a}, 2 \mathrm{~b}$, and $2 \mathrm{c}$, retaining the original setation), 3, 5, 7 and 9, which Fleminger termed the quadrithek pattern (Q). Male aesthetascs are of larger diameter and longer than female ones, and their clearly established function is detection of female mating hormones (Griffiths \& Frost 1976, Tsuda \& Miller 1998). Fleminger observed that a fraction of females in many (probably all) species of the Calanidae have the $Q$ pattern, although none of their aesthetascs show the masculine enlargement. He proposed that this results from switching by genetically male individuals to final development and maturation as females, the $\mathrm{Q}$ pattern being a trace of underlying male character. Fleminger (1985) also noted that a fraction of females have mixed patterns, with only some of $2 b, 3,5,7$ and 9 bearing extra aesthetascs. We have found those, also, and will refer to them as 'QT' females. Fleminger (1985) discounted them as simply aberrant.

Fleminger (1985) explained the possible value of switching from male to female as enhancement of the 
chances for an individual to survive, produce offspring, and contribute to the gene pool of future generations. There are several ways in which this could work. First, males in some populations have reduced feeding limbs (Brodskii 1950), particularly reduced dentition, so presumably are less well equipped than females to sustain themselves until mating opportunities arise. However, males of at least Calanus finmarchicus will survive in the laboratory for several months, and they do feed lightly and produce pale fecal pellets. On Georges Bank, males do have teeth (our obs.). Second, mating opportunities can be delayed by selecting male development. Male maturation typically precedes that of females (Marshall \& Orr 1955, Tande 1982, Durbin et al. 2000), forcing males to wait for females to mature. Switching to female maturation of 'genetic' males would give them first access to mating as a female, thus earliest reproduction in the stock. Third, a switching 'genetic' male might benefit from the lower adult mortality rate of females. When a low level of female mating pheromone is present, males engage in very vigorous horizontal swimming, searching for more concentrated vertical tracks of pheromone laid out by slowly sinking, mate-seeking females (Tsuda \& Miller 1998). This searching must greatly increase male encounters with predators, particularly ambush predators like chaetognaths and Euchaeta. Greater loss of males to predatory mortality is at least a partial explanation of the strongly female-skewed, adult sex ratios usual for most calanoids, although sex switching itself could skew the ratio toward females, as pointed out by Fleminger (1985). There is, of course, a tradeoff. By switching, a 'genetic' male would lose its potential for highly multiple matings and thus for genetic contribution to more than a single female's quota of eggs. Data for an exact cost-benefit analysis of switching are lacking.

Rearing studies also suggest that sex determination in Calanus is labile, possibly environmental and not chromosomal or otherwise genetic. It has long been possible to raise these copepods from eggs produced by females captured in the field (e.g. Mullin \& Brooks 1967), but typically all or nearly all individuals reaching maturity are female. Because mortality during rearing is never negligible, it has not been possible, until recently, to say that this is not due to mortality of juvenile males. However, the production of no males in very large cultures suggests that potential males may become females. It might be expected that this would produce very large fractions, perhaps up to half, of $\mathrm{Q}$ females, but that does not necessarily occur. For example, one rearing of Calanus finmarchicus by Pamela Blades-Eckelbarger and Nancy Marcus (pers. comm.) produced 200 females and 5 males. At most, 2 females from that supermajority were quadrithek. This sug- gests that a 'develop as female' (DF) cue during development can precede a 'grow extra aesthetascs cue, either preventing the latter signal or blocking its effect. Thus, it is possible that many more potential males can have switched to female maturation than are implied by the fraction of $\mathrm{Q}$ females in the adult stock. Quadrithek females would be only those switched males which received the DF cue after initiation of aesthetasc formation. Since extra aesthetascs develop as part of exoskeleton formation before the final molt from fifth copepodite (C5) to adult (C6), Q females are probably those that received the DF cue relatively late in C5. Gonads in a few individuals can develop into recognizable ovaries as early as $\mathrm{C} 4$ (authors' pers. obs.) so commitment to female development probably can come early.

An indication that commitment to male maturation is only fixed at some point in C5 comes from an experiment in 'partial' rearing of copepodites taken from the field, reported by Irigoien et al. (2000). Calanus helgolandicus copepodites were collected from the English Channel on several dates from early May through midJuly, then placed in 2 groups per stage (C5, C4 and $\mathrm{C} 2-3$ ) in rearing containers. There was some unfortunate confounding with date of collection, since all but one of the C5 experiments were started before the $\mathrm{C} 2-3$ and $\mathrm{C} 4$ experiments. Probably that made no difference. The 2 groups for each stage were given different food levels, 50 and 300 cells ml $^{-1}$ of Prorocentrum micans. In this experiment, food level had no effect, 45 to $95 \%$ of 70 to 80 C5 started on each date at each food level matured as males (Fig. 3 in Irigoien et al. 2000). Males exceeded $70 \%$ in 7 of 10 experiments. However, all but a few percent of equally large groups of $\mathrm{C} 4$ and C2-3 matured as females. It appears as if most of the C5 arrived at the laboratory with their sex already set, while some aspect of laboratory conditions drove all younger stages to female development. In this experiment, the mortality was 1 to 4 per group of $~ 80$ individuals, so differential mortality cannot account for the strong effect. Rather, sex determination appears to be environmentally influenced, whatever the underlying genetic mechanisms. Female development was favored by the laboratory situation, if an individual was exposed to it early enough. Why such large fractions, more than $70 \%$ for most collections, of animals that had nearly completed development in the field (the C5s) should have 'chosen' to be male over such a very long seasonal interval is puzzling. Females from these experiments were not examined in regard to antennular setation. High male:female sex ratios do occur in the field, typically at peaks of maturation when adult abundances are highest. A proportion of males exceeding $50 \%$ can be sustained for weeks at some sites, as shown by Figs. 5 to 9 of Irigoien et al. (2000). 
Marcus et al. (1999) performed an experiment of the same type as that reported by Irigoien et al. (2000, their Fig. 3) raising successive copepodite stages of Calanus finmarchicus collected from the Gulf of Maine. They found lower survivorship, but similar results (Table 1). Transfer to the lab at progressively earlier stages produced larger fractions of females, although female maturation was more common from all starting stages. In that case the female antennules were examined, and high fractions of $\mathrm{Q}$ females were found regardless of starting stage. We briefly report here another rearing experiment with $C$. finmarchicus from the Gulf of Maine with an informative, if difficult to interpret, outcome.

Recent rearing work with different phytoplankton species as food and rearing in very large containers has finally begun to produce larger numbers of males. Irigoien et al. (2000) suggest from a summary of this work that there is a positive relation between the fraction of individuals maturing as males and the quantity of suitably high quality food during growth. In some of the experiments different food levels were supplied throughout rearing of different groups, and proportion of males varied accordingly. Provision of specific dinoflagellates appears to be helpful, promoting both vigorous growth and substantial fractions of matured males. Some mesocosm rearings with high food levels in Norwegian fjords (Irigoien et al. 2000) consistently produced greater than $50 \%$ and up to $~ 80 \%$ males, the potential for which changes the picture of sex determination sharply. In Fleminger's (1985) view, the likely mechanism leading to highly variable sex ratios was a conversion of 'genetic' males to final maturation as functional females. However, a fraction of genetic males as great as 4 in 5 seems very unlikely, and the mechanism determining sex in Calanidae is suggested to be primarily a response to some aspects of the environment. It is also evident from results cited by Irigoien et al. (2000) and from other experiments that sex determination in laboratory rearing is strongly variable. It is likely that consistent, repeatable results can be obtained, but only with a very high level of control of conditions.

Table 1. Calanus finmarchicus. Rearing results for specimens collected as copepodites in the field then reared in the laboratory (Marcus et al. 1999). Diet was a mixture of 4 dinoflagellates. Q: quadrithek

\begin{tabular}{|lcccc|}
\hline $\begin{array}{l}\text { Starting } \\
\text { stage }\end{array}$ & $\begin{array}{c}\text { No. } \\
\text { males }\end{array}$ & $\begin{array}{c}\text { No. } \\
\text { females }\end{array}$ & \% survival & \% Q females \\
\hline C2 & 2 & 45 & 36 & 39 \\
C3 & 0 & 31 & 31 & 19 \\
C4 & 10 & 74 & 45 & 41 \\
C5 & 12 & 42 & 60 & 46 \\
\hline
\end{tabular}

Fleminger (1985) reviewed the substantial list of suggestions in the literature that sex determination is labile in copepods. Little has been added to that list since, even though the issues remain unresolved. Sex in several parasitic copepods has been shown to be environmentally determined (e.g. for the Notodelphyid Pachypygus gibber parasitic on ascidians by HipeauJacquotte 1988), and in some cases the mechanism has been determined (Do et al. 1984, Do \& Kajihara 1986, Kawasaki 1995, Becheikh et al. 1998, Michaud et al. 1999). Voordouw \& Anholt (2002) have suggested a mixed polygenic and environmental sex determination process in the harpacticoid Tigriopus. Harding (1963) suggested that Calanus finmarchicus has a pair of heterochromosomes and, therefore, that sex determination is probably chromosomal. Examination of the published micrographs of the chromosomes, however, does not lead to strong conviction that this is so. Crustacean chromosomes are small and difficult to distinguish, and those of Calanus are no exception. Many other species of calanoids are also said to have heterochromosomes (Heberer 1924, Goswami \& Goswami 1974), so some almost certainly do. Predominantly the systems appear to be XY/XX, in Acartia XO/XX. Other genera, notably Eurytemora (Vaas \& Pesch 1984), either do not have heterochromosomes or they are not morphologically distinct.

Even though at least one conserved DNA sequence has been identified among genes involved in sex determination (Raymond et al. 1998), the bifurcation to female or male development is among the least conserved developmental mechanisms in respect to genetic and enzymatic specifics (Marin \& Baker 1998). So, variation of sex determination within the Copepoda would not be surprising. In all crustacea studied to date, sex determination operates on an underlying female anatomical pattern which is converted to male development by the action of masculinizing hormone (e.g. Martin et al. 1999) secreted by a gland associated with the developmental rudiments of the gonad. A mass of glandular cells attached to the vas deferens of Calanus (P. Blades pers. comm.) may have this function. Detailed study of this gland and its function will be part of full description of sex determination mechanisms in Calanus and copepods generally, work which remains to be done.

Starting from the still to be verified assumption that $Q$ females have switched to female development after some progress toward male maturation, we have determined the seasonal variation of the frequencies of $Q$, QT and $\mathrm{T}$ females of Calanus finmarchicus over Georges Bank and in deeper surrounding waters. Fleminger (1985) suggested that QT individuals were not related to switching, just errors in the development of secondary sexual characters. In that sense, they 
would simply be examples of 'bearded ladies', females with a definite, if less strongly developed, male secondary sexual character despite being fully functional as females. Of course, it is just as likely that both Q and QT conditions are evidence of some sort of developmental masculinization, perhaps a partial response to a lateraborted pulse of masculinizing hormone. So, we treat them as equivalent in evaluating our data. We found both a strong seasonal pattern in $F Q=(Q+Q T) /(Q+Q T+T)$ and a strong difference from frequencies estimated in a northern Norwegian fjord. Therefore, we present the Georges Bank data here and discuss them in light of their possible implications in respect to sex determination in C. finmarchicus.

The Calanus finmarchicus stock in the Clyde Sea has a bimodal size distribution. Grigg et al. (1985) brought C5 from the

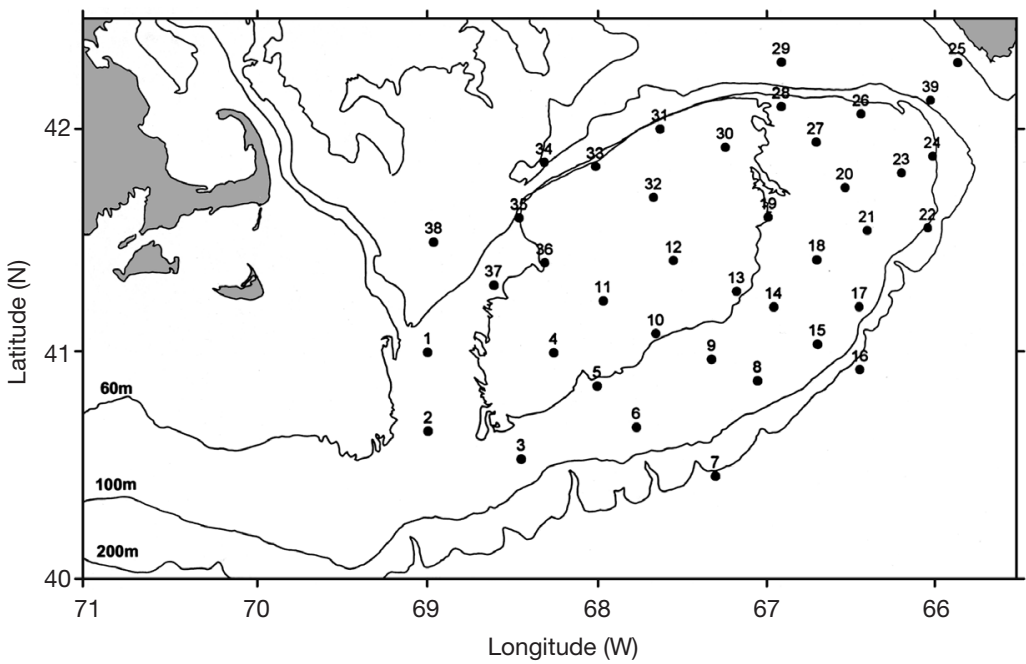

Fig. 1. Chart of U.S. GLOBEC Georges Bank Program Broad Scale Survey station locations, 1995 and 1996. Samples were collected in numerical order around the bank, except for the sequence 25, 39, 26. Thus the sampling sequence advanced upstream into the anticylconic flow around the bank

Clyde Sea to the laboratory, then compared lengths of their cast exoskeltons with the final sex of adult C6. All of the smaller mode matured as females. The larger mode produced both sexes, including the only males. Grigg et al. (1985), unaware of Fleminger's (1985) contribution, speculated that the larger mode were in some underlying sense male, part of them, however, completing development as females. Miller et al. (1991) measured C5 from south of Cape Cod, then classified them according to the development of gonadal rudiments. Those C5 developing testes were longer on average than those developing ovaries. Both observations suggest that, if $\mathrm{Q}$ and $\mathrm{QT}$ females derive from $\mathrm{C} 5$ which have started male development then switched, they might be expected to be longer on average than $\mathrm{T}$ females. Therefore, we have compared prosome lengths of Q, QT and T females on a monthly basis in the present observations.

Finally, we report a small set of antennular setation observations on Calanus finmarchicus females from the St. Lawrence estuary. These were taken from an egg production experiment, allowing a test of the relative fecundity of $\mathrm{Q}$ and $\mathrm{T}$ females.

\section{MATERIALS AND METHODS}

Quadrithek/trithek observations. Plankton collections were taken on the monthly, winter-spring, Broad Scale Survey cruises that were part of the U.S. GLOBEC Georges Bank Program in 1995 and 1996.
Survey stations (Fig. 1) were scattered over Georges Bank and in surrounding waters. Tows were made at each station with $333 \mu \mathrm{m}$ mesh bongo nets hauled obliquely to near the bottom or to a maximum of $500 \mathrm{~m}$ and with a $1 \mathrm{~m}^{2}$ MOCNESS net system (Wiebe et al. 1985) equipped with $150 \mu \mathrm{m}$ mesh. Target depth ranges for the MOCNESS were near-bottom or maximally 300 to $100 \mathrm{~m}, 100$ to $40 \mathrm{~m}, 40$ to $15 \mathrm{~m}$ and 15 to $0 \mathrm{~m}$. Subsamples from selected stations were taken at sea and returned to Oregon for study. Females were sorted from collections at a small, representative selection of those stations (Table 2), emphasizing stations

Table 2. Calanus finmarchicus. Source samples for females examined for antennular setation. The station grid is shown in Fig. 1. Station numbers refer to the Georges Bank Broad Scale Survey for 1995 and 1996; stations were run in numerical order, except 39 followed 25

\begin{tabular}{|llrlr|}
\hline Month & $\begin{array}{l}\text { Cruise } \\
\text { designation }\end{array}$ & Dates & Stations & $\begin{array}{r}\text { Total no. of } \\
\text { of females }\end{array}$ \\
\hline $\mathbf{1 9 9 5}$ & & & & \\
January & EN59 & $10-22$ & $38,2029,\left(42^{\circ} 15^{\prime} \mathrm{N}, 67^{\circ} 30^{\prime} \mathrm{W}\right)$ & 796 \\
February & EN261 & $10-20$ & $\begin{array}{l}8,13,16 \text { (all bongo tows) } \\
17,20,83,24,29,32,34,38\end{array}$ & 1114 \\
March & EN263 & $13-24$ & $3,8,11,21,24$, & 899 \\
& & & $38,\left(42^{\circ} 19^{\prime}\right.$ N, $\left.68^{\circ} 22^{\prime} \mathrm{W}\right)$ & \\
April & EN265 & $11-22$ & $3,8,23,239,38$ & 883 \\
May & AL9505 & $9-18$ & $9,21,26,34,38$ & 1017 \\
June & AL9506 & $5-15$ & $1,14,21,25,34,38$ & 816 \\
July & AL9508 & $10-20$ & $10,17,20,29,34,38$ & 730 \\
$\mathbf{1 9 9 6}$ & & & & 753 \\
January & EN276 & $10-20$ & $6,24,39,38$ & 528 \\
April & EN282 & $8-20$ & $3,21,29,38$ & 606 \\
June & AL9607 & $3-13$ & $6,24,39,38$ & \\
\hline
\end{tabular}


around the periphery where abundance of Calanus finmarchicus is usually higher, especially in spring (Durbin et al. 2000). For examination of Q, QT and T frequencies we sorted 100 females, when available, from both the deepest tow range and the near-surface sample. To reduce bias, specimens were taken as encountered in a grooved counting dish, except for the requirement that antennules retain at least 10 segments. A few males were sorted from scattered dates and stations and examined to see if the trithek pattern occurs with significant frequency among them.

Sorted specimens were transferred to glycerin in water solution on glass slides, left several days to stabilize, then measured for prosome length with an ocular micrometer $(\sim \pm 0.02 \mathrm{~mm})$. The right antennule was dissected, placed ventral side up in a small drop of glycerin solution, covered with a cover slip and examined by differential interference microscopy at 200 or 400 diameters. Individuals with the complete quadrithek pattern (Fig. 2a) were recorded as Q, those with a partial set of double aesthetascs as QT, those with the trithek pattern as $\mathrm{T}$ (Fig. 2b). Many aesthetascs are broken in the net, but the thin tubular base or a distinct ring in the surface exoskeleton always remains, making an accurate count possible for nearly all individuals.

Our large data set is based on female right antennules only. There are discrepancies between right and left antennules in the presence and completeness of the male aesthetasc pattern. We examined the left antennules for small samples of right- $Q$, right-T and right-QT females to evaluate the rates and extent of these variations (Table 3). By relying on data for just right antennules, a few percent of individuals with mixed patterns, if both antennules are considered, are misclassified as Q and as T. However, there is a strong contingency in counts of doubly occupied segments. In these small samples, right-Q females all had 3 or more quadrithek sites on the left; right- $T$ females had no more than one quadrithek site on the left. The bulk of right-QT females examined had low numbers of occupied sites, and results from the left antennule agreed. From the result for right-Q females, we assume that a sample of right-QT females selected from the relatively
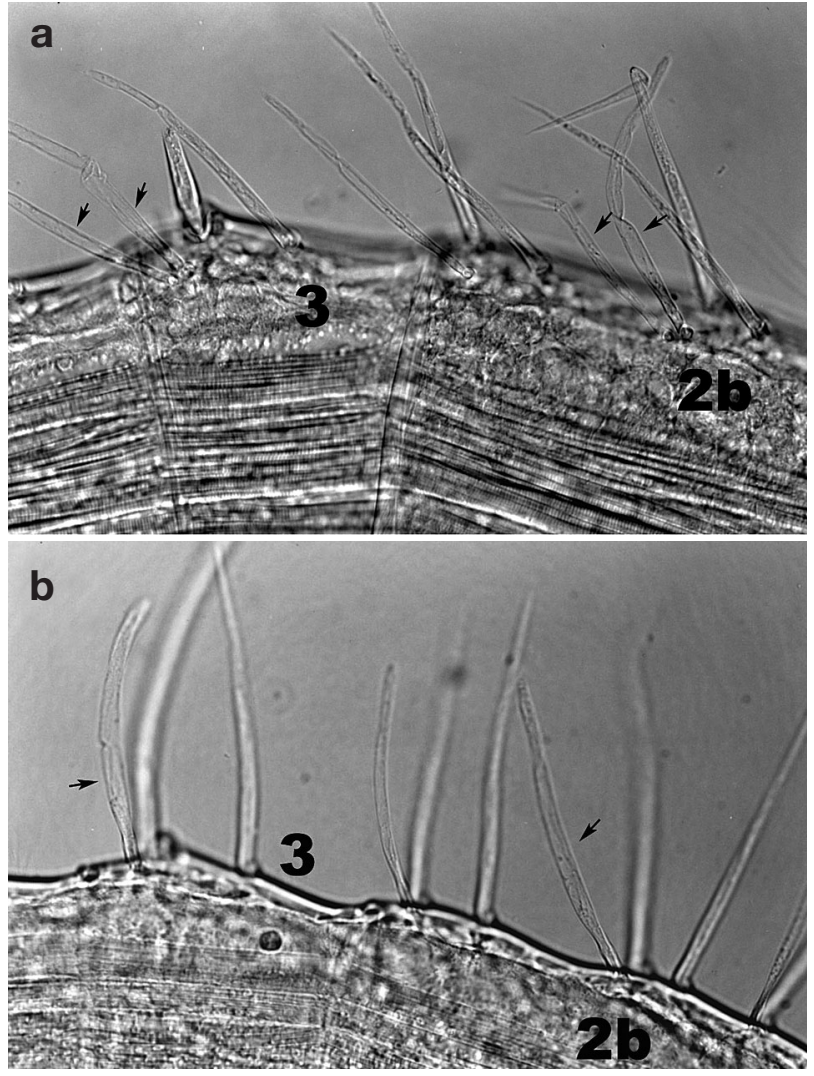

Fig. 2. Calanus finmarchicus female. Segments of the antennule (first antenna, A1). (a) Quadrithek setation pattern on Segments $2 \mathrm{~b}$ and 3 (labeled; arrows indicate aesthetascs). (b) Trithek setation pattern on Segments $2 \mathrm{~b}$ and 3 (labeled; arrows indicate aesthetascs)

few with 3 or 4 quadrithek sites would show more quadrithek sites on the left than did the group in our sample. In this analysis the specific sites occupied by 2 aesthetacs were recorded. While any of $2 b, 3,5,7$ or 9 can be the only quadrithek segments, the more distal ones tend to be favored. For example, among the 161 right-QT females with only 1 quadrithek segment, the sites with 2 aesthetascs were 18 on 2 b, 20 on 3,11 on 5 , 42 on 7,70 on 9 . That trend persisted for those with 2 quadrithek sites, 7-9 and 5-9 being favored over other

Table 3. Calanus finmarchicus females. Comparisons of aesthetasc counts on right A1 with aesthetasc counts on left A1. Q: quadrithek; T: trithek; QT: quadri-trithek

\begin{tabular}{|c|c|c|c|c|c|c|c|}
\hline \multicolumn{3}{|c|}{ Females $\mathrm{Q}$ and $\mathrm{T}$ on right $\mathrm{A1}$} & \multicolumn{5}{|c|}{ Females QT on right $\mathrm{A1}(\mathrm{N}=194)$} \\
\hline No. segments with extra & Q on right & $\mathrm{T}$ on right & $\begin{array}{l}\text { No. segments with extra } \\
\text { asthetascs on left A1 }\end{array}$ & \multicolumn{4}{|c|}{ No. segments with extra aesthetascs on right A1 } \\
\hline $0(\mathrm{~T})$ & 0 & 95 & $0(\mathrm{~T})$ & 124 & 11 & 3 & 0 \\
\hline 2 & 0 & 0 & 2 & 8 & 4 & 1 & 0 \\
\hline 3 & 1 & 0 & 3 & 3 & 4 & 1 & 0 \\
\hline 4 & 2 & 0 & 4 & 0 & 2 & 0 & 0 \\
\hline
\end{tabular}


combinations. The proportion of left-T antennules from right-QT females (138 of 194) seems high compared to the number of left-QT antennules from right-T females (5 of 100). However, $\mathrm{T}$ females are most abundant in general, so this follows the population proportions overall.

If we assume that neither left nor right is favored for a partial male pattern, these data imply that QT is somewhat underestimated by statistics from only 1 side (both some called $\mathrm{Q}$ and some called $\mathrm{T}$ would be $\mathrm{QT}$, if both sides were always examined), and that $\mathrm{T}$ and $\mathrm{Q}$ are both somewhat overestimated compared to a bilateral evaluation. However, we considered it more important to have large samples of individuals than to overcome these biases by examining both antennules on every individual. We simply accept that compared to bilateral data QT is somewhat underestimated, Q and $\mathrm{T}$ are somewhat overestimated.

Data were tabulated and subjected to contingency tests comparing nets within stations, stations within cruises and cruises. Despite extensive multiple testing, in only 2 cases were significant differences ( $5 \%$ level) found between depths. The deep net at Stn 29 in February 1995 had more Q and QT (28\% combined) than the surface net $(12 \%)$. A similar discrepancy in the same direction ( 25 vs. $12 \%$ ) occurred at Stn 23 in January 1996. In both cases, the mean for the station was very close to the mean for the month over all stations. Only 1 station (Stn 14, June 1995, represented by only 1 net and only 43 individuals) was significantly different (28\% Q and QT) from others $(12.5 \% \mathrm{Q}$ and QT overall) in its month. Therefore, all samples from each month were combined into a grand estimate of its $Q$, QT and T frequencies.

Relative fecundity of $\mathbf{Q}$ and $\mathbf{T}$ females. We examined antennules of preserved females from an egg production experiment conducted by Jeff Runge and Pierre Joly (Institut Maurice Lamontagne, Mont Joli, Quebec) in the St. Lawrence estuary $\left(48^{\circ} 40^{\prime} \mathrm{N}, 68^{\circ} 35^{\prime} \mathrm{W}\right.$, June, July and August 1997). Females were taken by net tow and held individually. Eggs from their first clutch after capture were counted. Thus, initial egg production rates of $\mathrm{Q}$ and $\mathrm{T}$ females can be compared.

A rearing experiment including photoperiod effects. A laboratory rearing of Calanus finmarchicus from eggs provides a test of some assumptions for interpretation of $\mathrm{Q}$ vs. T results. Eggs were obtained from females collected in the Gulf of Maine, North Atlantic, in February 1997. The eggs were placed in 4 separate, 191 carboys at a density of 300 eggs per carboy, or 16 eggs $\mathrm{l}^{-1}$. The carboys were divided between 2 environmental chambers, both set at a temperature of $15^{\circ} \mathrm{C}$ and initial photoperiod of 15:30 L/8:30 D. The copepods were fed a mixed diet of 4 dinoflagellates, Gymnodinium sanguineum (GSBL) (formerly Gymnodinium nelsoni and G. splendens), Lingulodinium polyedra (GP60) (formerly Gonyaulax polyedra), Prorocentrum micans (PRORO), and Scrippsiella trochoidea (PERI) (formerly Peridinium trochoidea) throughout the experiment, with 1 carboy in each environmental chamber receiving full food rations throughout (150 to 200 cells $\mathrm{ml}^{-1}$ final concentration of each species in a carboy), and the other reduced from full to half rations ( 75 to 100 cells ml ${ }^{-1}$ ) after $15 \mathrm{~d}$. For the duration of the $33 \mathrm{~d}$ experiment, the photoperiods are shown in Table 4, constant in one chamber, shortening in the other. At the end of the experimental period, the copepods were preserved in $10 \%$ formalin for examination. The numbers of males and females were counted, and right antennules from all females were examined for setal morphology.

Examination of females with $\mathbf{Q}$ antennules. Detailed microscopical observations were made of female Calanus finmarchicus specimens with antennular $\mathrm{Q}$ setation, seeking traces of other male secondary sexual characters.

\section{RESULTS}

\section{Males}

Examination of antennules from 112 males (from various Gulf of Maine/Georges Bank stations and dates) showed none with the trithek pattern, none with an incomplete quadrithek pattern. Setation of antennules was quadrithek in the entire small sample.

\section{Gulf of Maine Q vs. T proportions}

A larger fraction of Calanus finmarchicus females in the Georges Bank region have quadrithek antennular setation early in their active season, from January to July, than late in the season (Table 5, Fig. 3). The fraction FQ $=(\mathrm{Q}+\mathrm{QT}) /($ Total females $)$ was near $20 \%$ in January 1995, declined in succeeding months to $8 \%$ in April, then rose again to $12 \%$ in June, and $9 \%$ in July. The overall contingency $\chi^{2}$ for 1995 was $80.4(\mathrm{df}=5, \mathrm{p}<0.00001)$,

Table 4. Light regimes for 2 environmental chambers. L: hours of light; D: hours of dark in $24 \mathrm{~h}$

\begin{tabular}{|lcc|}
\hline \multirow{2}{*}{ Day } & \multicolumn{2}{c|}{ Photoperiod } \\
& Constant & Shortening \\
\hline $0-7$ & $15: 30 \mathrm{~L} / 8: 30 \mathrm{D}$ & $15: 30 \mathrm{~L} / 8: 30 \mathrm{D}$ \\
$8-14$ & unchanged & $15: 00 \mathrm{~L} / 9: 00 \mathrm{D}$ \\
$15-20$ & unchanged & $14: 30 \mathrm{~L} / 9: 30 \mathrm{D}$ \\
$21-26$ & unchanged & $14: 10 \mathrm{~L} / 9: 50 \mathrm{D}$ \\
$27-33$ & unchanged & $13: 49 \mathrm{~L} / 10: 11 \mathrm{D}$ \\
\hline
\end{tabular}


Table 5. Calanus finmarchicus females. Summary right antennular setation statistics for each month included in the study. Q: all segments quadrithek; QT: some segments quadrithek; T: all segments trithek

\begin{tabular}{|lcccccccccc|}
\hline & Jan 95 & Feb 95 & Mar 95 & Apr 95 & May 95 & Jun 95 & Jul 95 & Jan 96 & Apr 96 & Jun 96 \\
\hline Q & 116 & 143 & 98 & 52 & 65 & 62 & 40 & 108 & 48 \\
QT & 40 & 35 & 34 & 23 & 32 & 40 & 26 & 37 & 24 & 12 \\
T & 633 & 936 & 767 & 808 & 920 & 714 & 664 & 608 & 456 & 534 \\
Total & 789 & 1114 & 899 & 883 & 1017 & 816 & 730 & 753 & 528 & 606 \\
$\%(\mathrm{Q}+\mathrm{QT})$ & 19.77 & 15.98 & 14.68 & 8.49 & 9.54 & 12.50 & 9.04 & 19.26 & 13.64 & 11.88 \\
\hline
\end{tabular}

implying strongly significant differences in frequencies among months. Samples from January, April and June 1996 (Table 5, Fig. 3) showed the same pattern, although the spring months had somewhat higher fractions of $\mathrm{Q}$ and QT than the same months of 1995. There were always more $Q$ than QT females, although their relative numbers also had a significant seasonal pattern in 1995, Q dropping from 74 to $80 \%$ of Q + QT in early months to $61 \%$ in June and July 1995 (Fig. 4). July 1996 reversed this sequence, having the highest proportion of $\mathrm{Q}$ in $\mathrm{Q}+\mathrm{QT}$ of any month. However, the total sample size for these comparisons is modest in all months, only 72 for July 1996. Apart from that change, the general pattern was consistent in 2 successive years. As stated in the 'Materials and methods' section, there were essentially no significant differences in proportions of antennular types between deep and shallow samples or differences among stations in any month. The stock of the Gulf of Maine/Georges Bank region is uniform in this character at any given time.

Mean prosome lengths of Q, QT and T females were significantly different in some months, not in others (Table 6, Figs. $5 \&$ 6). However, the differences of means were always small, maximally $0.11 \mathrm{~mm}$. Early and late in 1995 the Q females were slightly larger, while the means were not significantly different in mid-

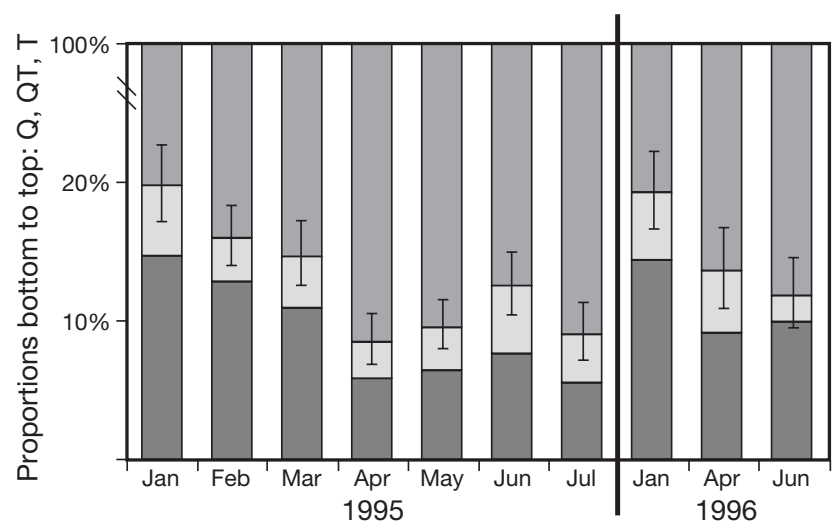

Fig. 3. Calanus finmarchicus females. Proportions of right antennules that were quadrithek (lower), QT (middle), and trithek (upper). Error bars are binomial 95\% confidence limits for $\%(\mathrm{Q}+\mathrm{QT})$

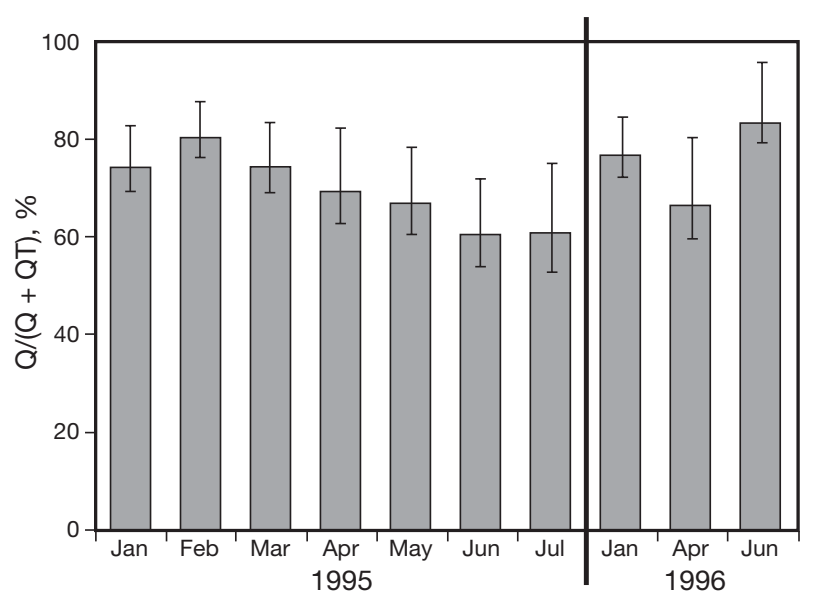

Fig. 4. Calanus finmarchicus female. Proportion of right antennules that were quadrithek on 5 segments (Q) compared to total that were quadrithek on any segment $(\mathrm{Q}+\mathrm{QT})$, with $95 \%$ binomial confidence limits

season. Q females were again slightly larger on average in January and June of 1996, but in April were actually slightly and significantly smaller. The length differences between $\mathrm{Q}$ and $\mathrm{T}$ females are of the same order as differences of mean length of $\mathrm{T}$ females (for which sample size allows useful testing) between depths at stations where deep samples $(>100 \mathrm{~m})$ were compared to shallow $(<15 \mathrm{~m})$. In such comparisons,

Table 6. Calanus finmarchicus females. Mean prosome length, together with probability that means are from different populations. Q: quadrithek; QT: quadri-trithek; T: trithek

\begin{tabular}{|c|c|c|c|c|}
\hline \multirow{2}{*}{$\begin{array}{l}\text { Month } \\
\text { and year }\end{array}$} & \multicolumn{3}{|c|}{ Mean prosome length (mm) } & \multirow{2}{*}{$\begin{array}{l}\mathrm{p} \text { from } \\
\text { ANOVA }\end{array}$} \\
\hline & Q & QT & $\mathrm{T}$ & \\
\hline Jan 95 & 2.504 & 2.425 & 2.399 & $<10 \mathrm{E}-08$ \\
\hline Feb 95 & 2.469 & 2.436 & 2.396 & $<10 \mathrm{E}-05$ \\
\hline Mar 95 & 2.554 & 2.517 & 2.532 & 0.560 \\
\hline Apr 95 & 2.673 & 2.743 & 2.690 & 0.320 \\
\hline May 95 & 2.619 & 2.561 & 2.568 & 0.100 \\
\hline Jun 95 & 2.793 & 2.749 & 2.706 & 0.001 \\
\hline Jul 95 & 2.743 & 2.764 & 2.677 & 0.004 \\
\hline Jan 96 & 2.473 & 2.397 & 2.387 & $<10 \mathrm{E}-5$ \\
\hline Apr 96 & 2.708 & 2.907 & 2.806 & 0.001 \\
\hline Jun 96 & 2.773 & 2.665 & 2.659 & 0.004 \\
\hline
\end{tabular}


mean prosome length of $\mathrm{T}$ females could vary significantly in either direction, but by a maximum of only $0.13 \mathrm{~mm}$. Because these depth differences were small and occurred in both directions, all measures for each month were combined to compare lengths of Q, QT and $\mathrm{T}$ females. The progressive increase in prosome length (Fig. 5) through the growing season is highly significant: month of collection explains $\geq 75 \%$ of variance in prosome length for females with each antennal type.

\section{Fecundity of $\mathbf{Q}$ and $\mathrm{T}$ females}

Female Calanus finmarchicus from the St. Lawrence estuary were larger, mean prosome length $3.1 \mathrm{~mm}$, than those from Georges Bank (Fig. 5). There was no significant difference in fecundity among Q, QT and T females (Table 7). Hatching rate and naupliar viability both ranged from 85 to $100 \%$ for all antennular groups. Thus, there was no apparent difference in the fecundity or reproductive success among $\mathrm{Q}, \mathrm{QT}$ and $\mathrm{T}$ females of C. finmarchicus.

\section{Rearing experiment comparing photoperiods}

Numbers of males and quadrithek, QT, and trithek females produced in each carboy are shown in Table 8. The ratio of males to females varied among the experimental treatments (Fig. 7). The chambers with constant day length, had smaller proportions of males (6 and 2 percent) than the chambers with the decreasing light regime ( 8 and 14 percent). Based on the results of this small study, it seems that amount of food did not have a consistent effect on the proportion of males produced, with fewer males in the half-ration carboy in the con-

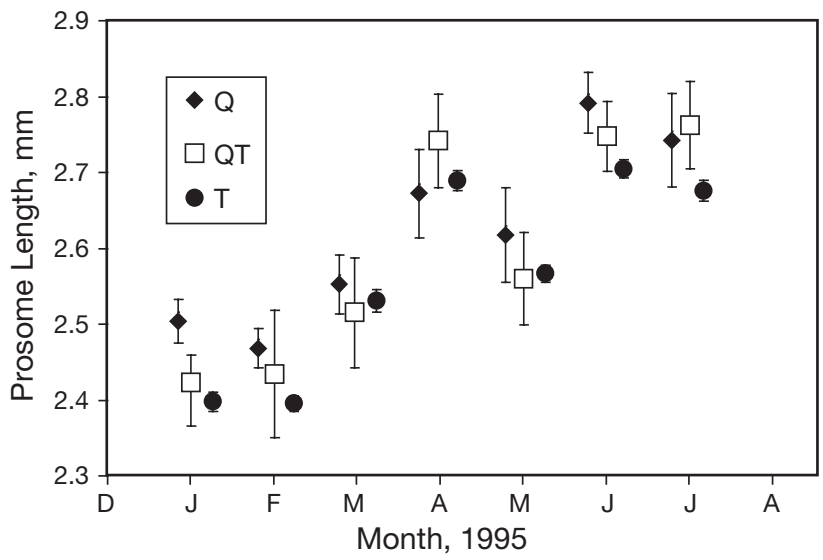

Fig. 5. Calanus finmarchicus female. Prosome length of $\mathrm{Q}$ (quadrithek), QT (quadri-trithek) and $\mathrm{T}$ (trithek, distinguished as in key at upper left) specimens in each month from January through July 1995. Error bars are 95\% confidence limits for the mean (1.96 SE)
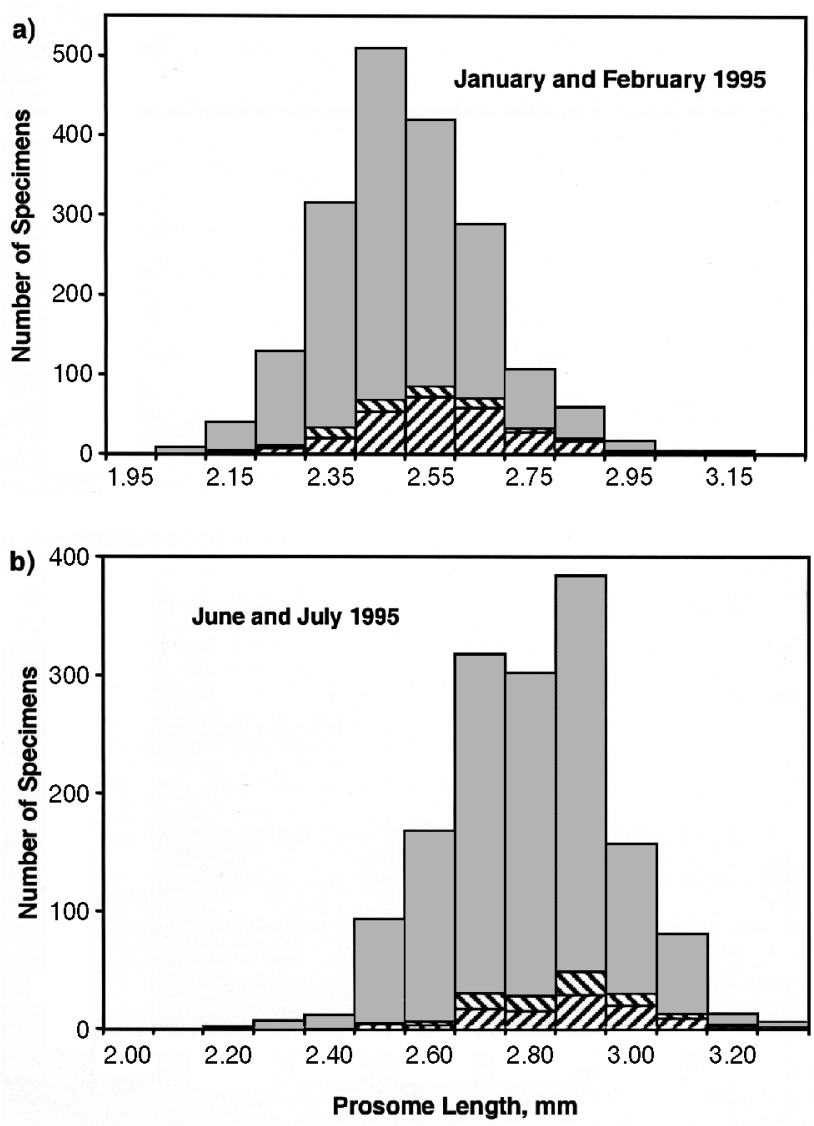

Fig. 6. Calanus finmarchicus female. Size-frequency histograms for prosome lengths of specimens from (a) the months with smallest sizes and (b) the months with largest sizes. Quadrithek $(\mathrm{Q}$, lower), quadri-trithek $(\mathrm{QT}$, middle), trithek ( $\mathrm{T}$, upper). Bars are labeled at mid-point of the range, e.g. a bar at 2.5 shows a count of females between 2.45 and $2.55 \mathrm{~mm}$. Grouping interval was shifted to show better the small differences in means between $\mathrm{Q}+\mathrm{QT}$ females and $\mathrm{T}$ females during each period

Table 7. Calanus finmarchicus. Number of eggs produced by females from the St. Lawrence estuary after $48 \mathrm{~h}$ in small containers with no food (data from J. Runge and P. Joly). Egg counts are presumed to be single clutches. Collections of 1996 were 14 and 21 August, 4 September. Collections of 1997 were 11 June, 22 July and 5 August. Q: quadrithek; QT: quadri-trithek; T: trithek

\begin{tabular}{|lrrrcr|}
\hline $\begin{array}{l}\text { Antennule } \\
\text { type }\end{array}$ & $\mathrm{N}$ & $\begin{array}{c}\text { No } \\
\text { eggs }\end{array}$ & $\begin{array}{c}<50 \\
\text { eggs }\end{array}$ & $\begin{array}{c}50-110 \\
\text { eggs }\end{array}$ & $\begin{array}{r}>110 \\
\text { eggs }\end{array}$ \\
\hline $\mathbf{1 9 9 6}$ & & & & & \\
Q & 18 & 7 & 0 & 8 & 3 \\
QT & 13 & 2 & 0 & 8 & 2 \\
T & 76 & 30 & 4 & 29 & 9 \\
$\mathbf{1 9 9 7}$ & & & & & \\
Q & 13 & 2 & 1 & 10 & 0 \\
QT & 19 & 1 & 1 & 15 & 2 \\
T & 81 & 5 & 8 & 55 & 10 \\
\hline
\end{tabular}


Table 8. Calanus finmarchicus. Males and quadrithek (Q), quadri-trithek (QT), and trithek (T) females produced in the 1997 rearing experiment. Q females bear an extra aesthetasc on Antennule Segments 2b, 3, 5, 7 and 9; QT females bear an extra aesthetasc on at least 1 but less than 5 of the aforementioned segments; T females bear no extra aesthetascs

\begin{tabular}{|lccccrr|r|}
\hline Chamber & Photoperiod & Food ration & Males & Q females & QT females & T females & N \\
\hline L1 & Fixed & $1 / 2$ & 5 & 4 & 18 & 56 \\
L2 & Fixed & Full & 4 & 3 & 27 & 92 \\
R1 & Decreasing & $1 / 2$ & 9 & 12 & 26 & 42 \\
R2 & Decreasing & Full & 11 & 19 & 16 & 34 \\
\hline
\end{tabular}

stant chamber, and more males in the half-ration carboy in the chamber with a decreasing light period.

Similarly, the proportions of females with Q, QT and $\mathrm{T}$ antennules varied among the experimental treatments (Fig. 7). Along with the larger proportion of males, there were larger proportions of Qs (14 and $24 \%$ ) and QTs (30 and 20\%) among the females in the decreasing photoperiod chamber than in the constant photoperiod one (5 and $2 \%$ Q, 22 and $22 \%$ QT). As with the males, food ration did not have a consistent effect on the number of Q or QT females produced.

\section{Examination of females with $\mathbf{Q}$ antennules}

A close examination of $Q$ females did not show partial development of the other secondary sexual characteristics of males. Q females have typical female prosome shape. The outline of the head is typical for females, and the antennal musculature is thin as in $\mathrm{T}$ females. Q females do not have any trace of the male cephalic hump (Nishida 1989). They do not have relatively longer thoracic legs at a given body size. Their proximal antennular segments are not enlarged, nor are their antennular articulations stiffened. They have no clavate seta on antennular segment 9. Caudal furcae of $Q$ females are not more rounded than those of $\mathrm{T}$ females, nor do they splay out to the sides. In sum, the only masculinized character we found in $\mathrm{Q}$ females was the quadrithek pattern of antennular aesthetascs.

\section{DISCUSSION}

\section{Variation in proportions of quadrithek females in a life-cycle context}

Calanus finmarchicus completes several life cycles in the Gulf of Maine and over Georges Bank between emerging from diapause in December-January and return to diapause in June-July. Durbin et al. (2000) show life cycle timing data from the 1995 and 1996 GLOBEC, Georges Bank Broad Scale Surveys, based on the same samples from which our female antennule data were generated. Following McLaren (1969), we term the generation of adults maturing out of diapause G0, its offspring G1, G1's offspring G2, and so on. It is very likely, given a strong April-May increase in C5 with large oil sacs at depth in the Gulf of Maine, that significant numbers of G1 individuals enter diapause rather than maturing immediately (Miller et al. 2000). A large increase in the abundance and proportion of

Fig. 7. Calanus finmarchicus. Pie charts showing proportions of males and quadrithek (Q), quadri-trithek (QT) and trithek (T) females produced in carboys held at (A) constant photoperiod and with (B) a progressively shortened photoperiod (Table 4). Left carboys were full nutrition; right were half ration 
males among adults (to $40-50 \%$ ) occurs in MarchApril, marking the maturation peak of the remaining fraction of G1 (Durbin et al. 2000, their Fig. 10). This peak in male abundance follows a March-April high in the fraction of developing gonads in C5 that are clearly testes (Crain \& Miller 2000). Relative abundance of adult males in the field is not a particularly good indicator of sex determination outcomes, because of (1) differential mortality with males usually dying faster, and (2) offset maturation timing with males in a cohort appearing first.

Most G2 individuals enter diapause, although some C5 have substantial gonad maturation in progress during June (Crain \& Miller 2000) and probably mature to produce G3. Each of these generational events is spread over substantial intervals, and thus they can overlap. Maturation of G0 occurs from early December into February, and G1 adults appear from March into May. Late copepodites (C3 to C5) of G2 can be present from April through July. Thus, there is considerable flexibility in life cycle choices by individual Calanus finmarchicus. Planque et al. (1997) and Planque \& Batten (2000) have compared regions within the range of the species and found that life history timing shifts from Norwegian Sea to Irminger Sea to Georges Bank. Thus, there is also flexibility in choices between stocks. Our present data suggest that sex determination is flexible as well.

If it is assumed, modifying the argument of Fleminger (1985), that Q and QT antennules (or even just Q antennules) identify females that advanced some way toward male development before switching to complete maturation as females, then changes in FQ among seasons, generations or sites imply a change in the factors controlling sex determination. FQ does vary seasonally in the Georges Bank region, and the variations correspond to the generational shifts. FQ is highest in G0, lowest in early G1, rising some again in late G1 or G2 adults. Most specifically the low values of FQ in April-May correspond with the jump in proportion of male adults, which Durbin et al. (2000) identified with maturation of G1. However, FQ did not vary across the region within months in excess of the expected limits of variability in estimates of proportions. If mid-course switching of sexual development to the opposite sex is adaptive to local or short-term changes in conditions, then our results imply that the effective conditions shift with season but are relatively constant across the sampling area. We propose that the inverse implication also holds. Because the rate of sex switching varies, it must be an adaptive feature of development.

Rates of sex switching late in development, if that is what is indicated by male antennular setation in females, also vary across the range of Calanus fin- marchicus as a whole. Svensen \& Tande (1999) determined the fraction of $Q$ females of $C$. finmarchicus in Malangen Fjord in northern Norway near Tromsø, where more than $95 \%$ of the stock completes only a single life cycle in the year (Tande 1982). They found $38 \% \mathrm{Q}$ in February (early maturers) and $25 \%$ in March. A small data set from fjord collections near Bergen (C. Rey pers. comm.), where there are 2 strong generations each year, showed $66 \%$ Q females $(\mathrm{N}=$ 63) in March, 4\%Q (N=52) in May. The initial fraction exceeds Svensen \& Tande's (1999) February result, and the seasonal change in fraction is in the same direction and greater than that at Georges Bank. Both observations strengthen the conclusion that sex determination varies with differences in habitat, suggesting that it is an adaptive mechanism.

Since the sex determination process for Calanus can produce a supermajority of females essentially without Q or QT antennules (the Blades-Eckelbarger and Marcus observations cited in the 'Introduction'), female maturation can certainly be fixed, and fixed for much more than half of a maturing stock, before any progress toward male development initiates development of quadrithek setation. Thus, it does not work to suppose that $\mathrm{T}$ females are half the maturing stock, males + Q-females the other half. All we obtain from estimates of FQ is assurance that sex determination, or just late sex switching, varies with season and location within the range.

Differences of mean prosome length between $Q$ and $\mathrm{T}$ females in our samples, even though significant in some months, cannot be used to infer anything about the sex determination process. The differences are too small and the distributions overlap too widely. The data of Grigg et al. (1985), obtained from the Clyde Sea stock, are convincing that in some localities males, and possibly males switched to female maturation, come almost exclusively from the larger half of the C5 stock. Our data do not show this pattern for Georges Bank. Female body size (Fig. 5) increased through the growing season, except for a reduction in May. Both the mean lengths for all females taken together and the trends agree with the larger set of stations examined by Durbin et al. (2000, their Fig. 11). Body size after diapause could be affected by diapause; perhaps January females maturing from the rest phase are simply small. However, it is very likely that diapausing C5 generated near or over Georges Bank are not those finally becoming G0 adults in the mid-winter maturation. Fifth copepodites of both G1 and G2 are larger (2.3 to $2.4 \mathrm{~mm}$ mean prosome length) than the C5 found in the southern Gulf of Maine resting stock in autumn (2.1 $\mathrm{mm}$ mean prosome length). An advective replacement during summer and autumn is likely. The January and February maturation sex ratio and FQ are 
set by the conditions experienced in development and rest by these immigrant C5. There is nothing to suggest what those conditions were.

We cannot identify from field data the habitat conditions influencing sex determination in Calanus finmarchicus. March to July size and sex determination outcomes should be set by conditions during the copepodite stages, that is during about $4 \mathrm{wk}$ before maturation. Temperature, which decreased from January to March then increased through the rest of the season (Fig. 8), did not correlate inversely with body size, as has been frequently observed for copepods (e.g. Deevey 1960), including C. finmarchicus (Marshall et al. 1934). However, a complex effect of temperature on size and final sex cannot be ruled out.

Availability of food is a candidate factor affecting sex ratios at maturation and proportion of $Q$ females. Several lines of evidence (Campbell et al. 2001, Crain \& Miller 2001) suggest that growth of Calanus finmarchicus in the vicinity of Georges Bank becomes food-limited for a period in mid-spring, which may explain the reduction in size of females in May. Characterizing food availability in the field is not simple, and measures like chlorophyll concentration are not good evaluations of trophic conditions, since the preferred food is protozoa (D. Gifford, Univ. Rhode Island, pers. comm.). However, food availability has been shown to influence sex determination in rearing experiments (Irigoien et al. 2000), with apparently better nutrition resulting in more males, even a supermajority of males. The direction of the shift in FQ we observe in the field appears to agree with these experimental results. If larger size implies better nutrition, and better

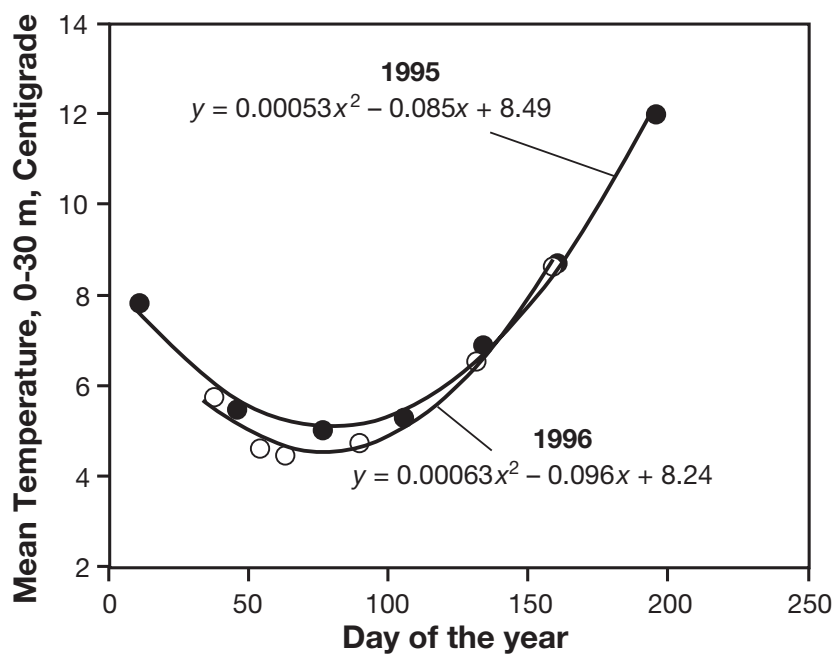

Fig. 8. Mean upper ocean temperatures $\left({ }^{\circ} \mathrm{C}, 0\right.$ to $30 \mathrm{~m}$ ) for 1995 and 1996 from the entire Broad Scale Survey region. Points for each cruise are plotted at its middle day; Day $1=$ January 1. Data provided by David Mountain, NMFS-NOAA, Northeast Fisheries Center, Woods Hole nutrition increases the proportion of individuals maturing as males, then we would also expect less late switching to female maturation when bodies are large. That is, the drop in FQ could be coupled to larger sizes and possibly to good nutrition. The May value of FQ did not increase when body size decreased, but possibly the determinations of adult body size and of final sex are several weeks out of phase. The data do not take us beyond these indefinite speculations.

\section{Photoperiod effects on maturation sex ratios}

Photoperiod is a candidate as a factor affecting the sex of Calanus at maturation, given the results of the 1997 rearing experiment. Photoperiod certainly varies between G0 maturation in January and G1 or G2 maturation in spring; it also varies with latitude. The experimental result was that slightly shortening photoperiod produced more males and $\mathrm{Q}$ females than constant photoperiod. Our field data show fewer $\mathrm{Q}$ females with lengthening photoperiod, which seems to agree with the experiment, but the field proportion of maturing males has not been estimated. Thus, the comparison is incomplete. More experimentation is indicated, which will require careful work with food quality and quantity as well as photoperiod.

\section{The sex determination mechanism in Calanus}

The extreme variation in sex ratio possible at maturation, shown by Irigoien et al. (2000) to range from nearly $100 \%$ female to greater than $90 \%$ male, strongly suggests that sex determination is under environmental control in Calanus. Of course, doubt must be retained until definitive experimental results become available. Numerous observations in older literature, cited by Fleminger (1985), suggest either sex switching or environmental sex determination in a number of calanoid and other copepods. However, if sex determination is environmental, or even if there is a genetic mechanism subject to switching by a secondary process, the factors to which sexual development responds are not well studied and the population dynamical consequences have not been examined.

Capacity of a maturing individual to select one sex or the other is apparently adaptive. The adaptive advantage of one sex over the other can be said a priori to be greater expectation of a contribution to future generations, more surviving F1, F2 or even later offspring. If males often fail to mate, but females usually succeed in finding males and accepting spermatophores, then female reproduction will be favored. That can also work in reverse; if many or most males die before 
mating (doubtless a common failure mode), then more males will be needed to insure a stock of fertilized eggs. Male maturation will be favored despite the high risk of death before mating. If males readily can participate in multiple matings, then male reproduction will be favored. Some aspect of the environment must provide information about mating prospects prior to maturation. It remains to demonstrate exactly how that works.

We do not claim that the proportions of Q and QT are particularly good indicators of the rates at which male or female maturation are elected, only that their variation, under certain assumptions, indicates seasonal and regional variation in those elections. From results we have cited, it is clear that in some instances a vast majority of individuals can elect female maturation with none or almost none of them having quadrithek antennules. The Q and QT aesthetasc patterns in females are most likely just evidence of switching after first initiation of male development in $\mathrm{C} 5$, the late arrival of the DF developmental cue. If so, the final sex determination decision can come very late in development. We also must retain the possibility that extra aesthetascs in females are unrelated to the main and effective sex determination process, that they are just a phenotypic variant variably expressed.

Copepods are the most successful marine mesozooplankton in terms of surviving species, number of individuals, production of biomass and occupation of varied habitats. Environmental sex determination is very likely a factor in that success. More secure proof that it occurs, full elucidation of the habitat factors to which sexual development responds, demonstration of the genetic and hormonal mechanisms of copepod sexual development and analysis of the selective consequences of resulting sex ratios all remain before us.

Acknowledgements. This study was supported by NSF Grants OCE-9317506 and OCE-9618578. It is U.S. GLOBEC contribution no. 249. We thank all our Georges Bank GLOBEC colleagues for their work at sea and helpful discussions. We thank Jeffery Runge for sharing data and specimens from egg production and viability experiments and David Mountain for summaries of Georges Bank Broadscale temperature data.

\section{LITERATURE CITED}

Becheikh S, Michaud M, Thomas F, Raibaut A, Renaud F (1998) Roles of resource and partner availability in sex determination in a parasitic copepod. Proc R Soc Lond B 2665:1153-1156

Brodsii KA (1950) Veslonogie rachki Calanoida Dal'nevostochnykh morei SSSR i Polyarnogo basseina. Keys to the Fauna of the USSR, No. 35. Akad Nauk SSSR, Zool Inst, Moscow-Leningrad. (Transl.: Mercado A [1967] Calanoida of the far eastern seas and polar basin of the USSR, Israel Prog Sci Transl, Jerusalem)
Campbell RG, Wagner M, Teegarden GJ, Boudreau CA, Durbin EG (2001) Development and growth rates of the copepod Calanus finmarchicus reared in the laboratory. Mar Ecol Prog Ser 221:161-183

Crain JA, Miller CB (2000) Detection of sex and sex ratio in Calanus finmarchicus early stage fifth copepodites. ICES J Mar Sci 57:1773-1779

Crain JA, Miller CB (2001) Effects of starvation on intermolt development in Calanus finmarchicus copepodites: a comparison between theoretical models and field studies. Deep-Sea Res II 48:551-566

Do TT, Kajihara T (1986) Studies on parasitic copepod fauna and biology of Pseudomyicola spinosus, associated with blue mussel, Mytilus edulis galloprovincialis in Japan. Bull Ocean Res Inst Univ Tokyo 23:1-63

Do TT, Kajihara T, Ho J-S (1984) The life history of Pseudomyicola spinosus (Raffaele \& Monticelli 1885) from the blue mussel, Mytilus edulis galloprovincialis in Tokyo Bay, Japan, with notes on the production of atypical male. Bull Ocean Res Inst Univ Tokyo 17:1-65

Deevey GB (1960) Relative effects of temperature and food on seasonal variations in length of marine copepods in some eastern American and western European waters. Bull Bingham Oceanogr Coll 17:55-86

Durbin EG, Garrahan PR, Casas MC (2000) Abundance and distribution of Calanus finmarchicus on the Georges Bank during 1995 and 1996. ICES J Mar Sci 57:1664-1685

Fisher RA (1930) The genetical theory of natural selection. Clarendon Press, Oxford

Fleminger A (1985) Dimorphism and possible sex change in copepods of the family Calanidae. Mar Biol 88:273-294

Goswami U, Goswami SC (1974) Cytotaxonomical studies on some calanoid copepods. Nucleus 17:109-113

Griffiths AM, Frost BW (1976) Chemical communications in the marine planktonic copepods Calanus pacificus and Pseudocalanus sp. Crustaceana 30:1-9

Grigg H, Holmes LJ, Bardwell S (1985) Seasonal observations on the biometry and development in copepodite stage $\mathrm{V}$ of Calanus finmarchicus from the Firth of Clyde. Mar Biol 88:73-83

Harding JP (1963) The chromosomes of Calanus finmarchicus and C. helgolandicus. Crustaceana 6:81-88

Heberer G (1924) Die Spermatogenese der Copepoden. I. Die Spermatogenese der Centropagiden nebst Anhang über die Oogenese der Diaptomus castor. Z Wiss Zool 142:191-253

Hipeau-Jacquotte R (1988) Environmental sex determination in a crustacean parasite. Int J Invert Reprod Biol 14:11-23

Irigoien X, Obermüller B, Head RN, Harris RP and 5 others (2000) The effect of food on the determination of sex ratio in Calanus spp.: evidence from experimental studies and field data. ICES J Mar Sci 57:1752-1763

Kawasaki N (1995) Sex determining pheromone of poecilostomatoid copepod Pseudomyicola spinosus (Raffaele \& Monticelli 1885), associated with bivalves. BE thesis, Soka Univ, Hachioji, Tokyo

Marcus NH, Blades-Eckelbarger P, Crain JA (1999) Sex ratio and sex switching in Calanus: environmental effects. Poster, TASC Symposium: the population dynamics of Calanus in the North Atlantic, results from the TransAtlantic Study of Calanus program. Tromsø, Norway, August 1999

Marin I, Baker BS (1998) The evolutionary dynamics of sex determination. Science 281:1990-1994

Marshall SM, Nicholls AG, Orr AP (1934) On the biology of Calanus finmarchicus. Part V. Seasonal distribution, size, 
weight and chemical composition in Loch Striven in 1933 and their relation to the phytoplankton. J Mar Biol Assoc UK 19:793-828

Marshall SM, Orr AP (1955) The biology of a marine copepod Calanus finmarchicus (Gunnerus). Oliver and Boyd, Edinburgh

Martin, G, Sorokine O, Moniatte M, Bulet P, Hetru C, VanDorsselaer A (1999) The structure of a glycosylated protein hormone responsible for sex determination in the isopod, Armadillidium volgare. Eur J Biochem 262:727-736

McLaren I (1969) Population and production ecology of zooplankton in Ogac Lake, a landlocked fjord on Baffin Island. J Fish Res Bd Can 26:1485-1559

Michaud M, Thomas F, Becheikh S, Raibaut A, Shykoff JA, Renaud F (1999) Stage-dependent decisions in a parasitic copepod practicing environmental sex determination. Mar Ecol Prog Ser 185:189-193

Miller CB, Cowles TJ, Wiebe PH, Copley NJ, Grigg H (1991) Phenology in Calanus finmarchicus; hypotheses about control mechanisms. Mar Ecol Prog Ser 72:79-91

Miller CB, Crain JA, Morgan CA (2000) Oil storage variability in Calanus finmarchicus. ICES J Mar Sci 57:1786-1799

Mullin MM, Brooks ER (1967) Laboratory culture, growth rate, and feeding behavior of a planktonic marine copepod. Limnol Oceanogr 12:657-666

Nishida S (1989) Distribution, structure and importance of the cephalic dorsal hump, a new sensory organ in calanoid copepods. Mar Biol 101:173-185

Planque B, Batten SD (2000) Calanus finmarchicus in the

Editorial responsibility: Michael Landry (Contributing Editor), La Jolla, California, USA
North Atlantic: the year of Calanus in the context of interdecadal change. ICES J Mar Sci 57:1528-1535

Planque B, Hays GC, Ibanez F, Gamble JC (1997) Large-scale spatial variations in the seasonal abundance of Calanus finmarchicus. Deep-Sea Res 44:315-326

Raymond RS, Shamu CE, Shen MM, Seiferts KJ, Hirsch B, Hodgkin J, Zarkower D (1998). Evidence for evolutionary conservation of sex-determining genes. Nature 391: 691-693

Svensen C, Tande K (1999) Sex change and female dimorphism in Calanus finmarchicus. Mar Ecol Prog Ser 176: 93-102

Tande K (1982) Ecological investigations on the zooplankton community of Balsfjorden, northern Norway: generation cycles, and variations in body weight and body content of carbon and nitrogen related to overwintering and reproduction in the copepod Calanus finmarchicus (Gunnerus). J Exp Mar Biol Ecol 62:129-142

Tsuda A, Miller CB (1998) Mate-finding behavior in Calanus marshallae Frost. Phil Trans R Soc Lond B 353:713-720

Vaas P, Pesch GG (1984) A karyological study of the calanoid copepod Eurytemora affinis. J Crustac Biol 4:248-251

Voordouw MJ, Anholt BR (2002) Heritability of sex tendency in a harpacticoid copepod, Tigriopus californicus. Evolution 56:1754-1763

Wiebe PH, Morton AW, Bradley AM, Backus RH, Craddock JE, Barber V, Cowles TJ, Flierl GR (1985) New developments in the MOCNESS, an apparatus for sampling zooplankton and micronekton. Mar Biol 87:313-323

Submitted: September 15, 2001; Accepted: May 10, 2005 Proofs received from author(s): September 22, 2005 